\title{
The effects of local fiscal policy on firm profitability
}

\begin{abstract}
Since decades, scholars and policy makers have been interested in how fiscal policy influences entrepreneurship. Until now, research has focused on fiscal policy at the federal or regional level and used macro-economic outcome measures. Considerably less attention was given to how municipal governments can influence economic outcomes at the micro level. The present study examines the effect of municipal taxes, spending and tax compliance costs on firm profitability within the Flemish hospitality industry. This is a unique research setting, since Flemish municipalities have far-ranging fiscal autonomy which has resulted in a proliferation of local taxes, many of which are specific to the hospitality industry. The findings reveal that local taxes have a negative impact on firm profitability, while aggregate public spending has a positive influence. While both influences are economically significant, the tax effect exceeds the public spending impact. Finally, we find no impact of compliance costs from local taxes.
\end{abstract}




\section{Introduction}

Since decades, scholars and policy makers have been interested in how fiscal policy influences entrepreneurship (Jofre-Monseny \& Solé-Ollé, 2010). However, until now, literature on fiscal policy mostly examined the effect of federal taxes and spending, and the studies that do focus on the local level, limit it to the level of the county. Research on the effects of municipal fiscal policy is scant. Notable exceptions include Becker, Egger and Merlo (2012), Gabe and Bell (2004), and Jofre-Monseny and Solé-Ollé (2010). There are several reasons to believe that the findings of the research at the federal level are not transferable as such to the local level. Some authors have already stressed that the effect of taxes will be more pronounced when studied at smaller geographical scales (Bartik, 1992; Phillips \& Goss, 1995; Wasylenko, 1997). Their argument is based on the fact that there is a smaller variation of business conditions within regions. Consequently, at the local level, tax differentials are considered as one of the few aspects that can affect firm behavior. Regarding public spending, Munnell (1992) and Munnell and Cook (1990) argued that the effect of public capital diminishes if the geographic area narrows. Indeed, small regions cannot capture all the benefits of the infrastructure investment because of leakages. Their findings were corroborated by Berechman, Ozmen and Ozbay (2006). On the other hand, local governments are closer to the users of the public capital than the federal government, and can therefore, better anticipate the needs of the companies established within their borders. This potentially increases the effectiveness of local spending at the local government level. 
Another particular feature of our study is the use of firm-specific or micro-variables. Studies evaluating the effects of local fiscal policy most often focus on aggregate outcome measures, such as aggregate employment growth (e.g. Mark, McGuire, \& Papke, 2000), business location (e.g. Feld \& Kirchgässner, 2002) or growth in personal income per region (e.g. Helms, 1985). A recent trend in the current research is the use of outcome measures at the firm level. For instance, Duranton, Gobillon and Overman (2011) showed that local taxes had a negative impact on firm employment growth. An advantage of using firm-level data is that more information is available for controlling for firm-specific variables in the regression, reducing the potential of omitted variable bias.

For this study, our preferred company-level measure for the evaluation of success of municipal policy is profitability. Profitability is a frequently used measure of firm financial performance (Gedajlovic \& Shapiro, 2002; Goddard et al., 2009) as it is the main concern for company owners and managers and a prerequisite for long-term viability. Ultimately, the succes of a firm depends on its profits (Huang \& Chaloupka, 2013). Furthermore, municipal government action may affect both revenues and costs, so in that sense, profitability is a comprehensive measure.

Local fiscal policy not only causes costs to the companies in terms of tax payments, but also in terms of compliance costs. Over the last decades, there has been a growing interest in the amount of compliance costs associated with taxes. Numerous studies, all over the world, have attempted to estimate the amount of compliance costs associated with certain taxes (e.g. Ariff, Ismail, \& Loh, 1997; Hanefah, Ariff, \& Kasipillai, 2002; Klun \& Blazic, 2005). However, in these studies most of the attention was given to VAT, labour taxes and income tax (e.g. Gupta \& Mills, 2003; Slemrod \& Blumenthal, 1996; Smulders \& Stiglingh, 2008). To 
the best of our knowledge, no attempts have been made to examine whether local taxes also generate substantial compliance costs and whether this can have an influence on firm performance.

In short, this paper aims to examine the effects of local taxes, local public spending and tax compliance costs on firm profitability. The context in which we try to address these research questions is the Flemish hospitality industry, which is an interesting area of research. Flemish municipalities have a high degree of fiscal autonomy and there is a real proliferation of municipal taxes. A lot of these local taxes are specific to the hospitality industry (Laureys \& Van Assche, 2012). Therefore, we have chosen the hospitality industry as our research context. By focusing on the hospitality industry, we contribute to the literature, since the few studies using micro data tend to focus on manufacturing (Wasylenko, 1997; Fisher, 1997). However, the results from these studies cannot easily be extended to other sectors, since the effect of public services as well as taxes may differ across industries (Fisher, 1997). Furthermore, it is argued that research that focuses on a particular industry, will provide more reliable estimates (Cohen \& Morrison Paul, 2004).

In order to answer the research questions, we use a dataset of 3,069 firm-year observations over the period 2004-2007, using regression analysis with firm-specific effects. We show that local fiscal policy has a non-negligible impact on the performance of hospitality firms. More specifically, local taxes are found to have a negative economic significant effect on firm performance that exceeds the positive effect of public spending. When examined more in detail, we found that of the separate spending categories only 'other productive spending' seems to influence firm profitability significantly. The compliance costs associated with local taxes appears not to impact firm financial performance. 
The remainder of this paper is structured as follows. The next section gives a literature review on the different aspects of local fiscal policy (i.e. Local taxes, local spending, tax compliance costs) and profitability. In the third section the fiscal situation of the Flemish municipalities is explained and the methodology and data are described. Results are presented in section four. Section five presents some robustness checks. Section six discusses the findings and conclusions are drawn in the final section.

\section{Literature review}

We will first discuss the empirical literature on the effects of the different aspects of local public finance, to wit; local taxes, government spending and tax compliance cost. Secondly we will present the literature on profitability and its determinants.

\section{Local taxes}

Most of the studies on local fiscal policy focus on how taxes affect inter alia income, employment, and investment at the state level (Wasylenko, 1997). The findings of these studies vary greatly. Tannenwald (1996), for example, found no effect of local taxes on businesses' capital spending. More recently, Bruce and Deskins (2012) also concluded that state tax policies generally do not appear to impact entrepreneurial activity significantly. Contrary to these two studies, Feld and Kirchgässner (2002) and Holcombe and Lacombe (2004) demonstrated that taxes do have negative economic outcomes. Reviewing the prior literature, Wasylenko (1997) concluded that the interregional studies generally found statistically significant, but economically unimportant effects. In another review, Bartik (1992) reported that the elasticity of state or metropolitan area business activity with respect to state and local taxes varies between -0.15 and -0.85 . These differences between papers are partly due to methodological issues. It has been argued that the effect of taxes 
intensifies once region-specific effects are included (Bartik, 1992) and that it is underestimated when public spending variables are excluded (Phillips \& Goss, 1995).

Research on the effect of local municipal taxes is still scarce and the exact influence is unknown. Gabe and Bell (2004), for example, indicated that firms prefer municipalities that spend high amounts on public goods and services even when these are financed by tax increases. Looking at municipalities in Catalonia, Jofre-Monseny and Solé-Ollé (2010) found that increases in local taxes deter the creation of new manufacturing establishments. Rathelot and Sillard (2008) concluded that higher local taxes have a negative effect on business formation, but that the effect is weak. So, the effect of local taxes at municipal level is still unclear.

\section{Local public spending}

Next to taxes, public spending also received considerable attention in the literature starting with the work of Aschauer (1989), who found that national public infrastructure had an enormous impact on private sector performance. The surprising magnitude of his results fostered research on the economic effect of public spending, not only at the national, but also at local levels. Munnell (1992) and Munnell and Cook (1990), for example found positive effects on state-level output, but they argued that the effect of public capital diminishes if the geographic area narrows. Indeed, small regions cannot capture all the benefits of the infrastructure investment because of leakages. Their findings were corroborated by Berechman, Ozmen and Ozbay (2006).

It is generally found that local public spending has a positive economic effect. Three specific types of local spending have been considered as productive (Brülhart, Jametti, \& Schmidheiny, 2012) and are often encountered in the literature (Fisher, 1997), i.e. spending 
on education, highways and safety. These spending categories are said to improve firm productivity. Firms in the hospitality industry can also benefit from local spending, since it can serve as an input in the service process, can enhance the attractiveness of the region for customers and they can improve the quality of life. Therefore, a region can become more attractive for tourism, which may in turn heighten demand and hence positively affect firm profitability.

\section{Tax compliance costs}

Local taxes not only comprise the cost of the tax payment, but also bring forth compliance costs. These compliance costs are defined as the costs to taxpayers "in meeting the requirements laid upon them in complying with a given structure and level of tax" (Sandford, Godwin, \& Hardwick, 1989, p.10). Smulders and Stiglingh (2008) indentify four types of compliance costs: (1) the costs of time spent in order to acquire knowledge on the tax law; (2) the record-keeping costs; (3) the payments made for outside experts; (4) incidental costs, such as costs for travelling, postage, and computer software.

Compliance costs have long be treated as hidden costs (Tran-Nam, Evans, Walpole, \& Ritchie, 2000). Nowadays, however, compliance costs are considered as a major economic waste, since they reduce firms' resources, while not increasing governments' revenue (Eichfelder \& Schorn, 2012). High compliance costs can hamper firm profitability and can consequently reduce economic growth, since entrepreneurs prefer to finance investments and growth from retained profits (Chittenden, Poutziouris, Michaelas, \& Watts, 1999). In the same vein, a recent tax study of PricewaterhouseCoopers (2013) indicated that countries with less administrative complexity experience a growth in gross domestic product. Being 
aware of the adverse effects of compliance costs on firm performance, governments all over the world consider compliance costs, when imposing new tax regulations.

Nowadays, a large literature has emerged that attempts to estimate the amount of compliance costs. Pope, Fayle and Chen (1991), for example calculated that for Australian public companies compliance costs with respect to income taxation ranged between 11.4 and $23.7 \%$ of tax revenue collected from these companies. Sandford et al. (1989), on the other hand, showed that UK companies on average incurred compliance costs of $2.2 \%$ of tax revenue. Recently, in Flanders, compliance costs of SMEs have been estimated to account for $7 \%$ of gross added value (Schoonjans, Van Cauwenberge, Reekmans \& Simoens, 2011).

Several authors have stressed that compliance costs might differ strongly across industries (e.g. Slemrod \& Blumenthal, 1996). However, there is no consensus about which industries carry the heaviest compliance burden (Schoonjans et al., 2011). Another recurrent theme in the compliance cost literature is the regressivity hypothesis, which means that smaller firms are burdened with relatively higher compliance costs. This was evidenced by, for example, Chittenden, Kauser and Poutziouris (2003), Hanefah et al. (2002), and Smulders and Stiglingh (2008). Finally, it has been acknowledged that different taxes generate different compliance costs (Tran-Nam et al., 2000). Generally, VAT is considered as the most burdensome taxes in terms of compliance costs (Schoonjans et al., 2011; Smulders \& Stiglingh, 2008). However, to the best of our knowledge, no attempts have been made to examine the effect of compliance costs associated with local taxes.

\section{Profitability}

Some examples of well-known profitability studies are Goddard et al., 2009 and Nunes et al., 2009. Most profitability studies include the same firm-specific control variables: age, size and 
leverage. Age accounts for lifecycle effects. Established firms can experience learning effects and can benefit from a well-known brand (Madanoglu, Lee, \& Castrogiovanni, 2011) and a stable customer base, which can result in a higher level of firm profitability. Conversely, older firms are more stuck in routines and do not react as easily to changing market preferences as compared to younger firms (Douma, George, \& Kabir, 2006). So, a priori, both a positive and a negative coefficient of the age variable can be expected (Glancey, 1998).

The second control variable, size, is one of the most frequently encountered variables in research examining the profitability of firms (Capon, Farley, \& Hoenig, 1990; Douma et al., 2006 ). However, the findings of studies assessing the relationship between size and financial performance are rather inconclusive. Theory predicts that both a positive and a negative effect could be found. On the one hand, larger firms can benefit from scale economies, can diversify their product range and can more easily control the market (Serrasqueiro \& Nunes, 2008). As for hotels, for example, larger hotels can offer more facilities, since the fixed costs of these facilities can be spread over more rooms. These existing facilities can attract more customers, which will result in higher demand and higher firm profitability. Furthermore, larger firms tend to spend more on advertising (Chung \& Kalnins, 2001), thereby increasing awareness by potential customers, which may in turn result in increased patronage. On the other hand, based on the agency theory, a negative relationship between firm size and financial performance can be expected. The interest of owners and managers differ, since owners are interested in company profits, while managers aim to achieve personal welfare. In larger firms, it is more difficult to control managers, who can thus pursue their own goals, which may result in lower firm profitability (Nunes, Serrasqueiro, \& Sequeira, 2009). In our sample, most of the firms are small and probably are managed by the owner. Therefore, the 
the agency issues may be rather limited. A special feature related to size arises when taxation is not results-based, as is the case in the Flemish municipalities. This 'lump sum' aspect raises the expectation that municipal taxation should weigh relatively more on smaller companies, which motivates the inclusion of an interaction term between size and taxation.

The last firm-specific control variable is leverage. Similar to age and size, theory suggests that leverage can influence firm profitability both positively and negatively. On the one hand, debt encourages managers and owners to manage the company more efficiently, since they have to repay the debt and pay the interest. These payments also reduces free cash flow (Jensen, 1986), thereby reducing agency problems, since there is less money available to invest in prestigious projects. Again, because our sample contains mostly small companies, the agency issues will potentially be limited. On the other hand, debt lenders tend to attach restrictive conditions to the granting of debt (Jensen \& Meckling, 1976), which may actually limit the money necessary for investment opportunities (Nunes et al., 2009).

\section{Methodology and data}

\section{Flemish context}

Flanders is one of the three regions in Belgium, where there are four levels of fiscal autonomy. Taxes are levied at the federal, regional, provincial and the local municipal level. Compared to other countries in the world, the local governments have a high degree of fiscal autonomy (Leroy, 2005). The kinds of local taxes that are levied by the municipalities depend on the local needs and are often issued to compensate negative externalities of firms, for example taxes on environmental issues (Smolders et al., 2005). Generally, there are two 
types of local taxes: the surcharges imposed on taxes levied at higher government levels and the own local taxes. The surcharges on the property tax and the personal income tax belong to the first tax type. Examples on the second type include all kinds of personal as well as business taxes, such as a tax on employees, on pavements, on the distribution on advertising brochures etc. Total tax revenue amounts to almost $50 \%$ of total revenue for the local governments, while the other $50 \%$ is mainly composed of grants received from higher governmental levels. The importance of taxes in the composition of the municipal budgets is increasing over time (Leroy, 2005). The surcharges on the property tax and the personal income tax account for $80 \%$ of municipal tax revenue. Over the period $1992-2002$, the own local business taxes amount to $6.9 \%$ of the municipal tax revenue and correspond to an average tax spending of 1000 euro per company (Smolders et al., 2005). In 2002, there were in total 126 different local taxes, of which 45 were imposed on businesses and the selfemployed (Smolders et al., 2005). Furthermore, 11 of the local taxes appeared in less than 5 municipalities (Smolders et al., 2005). On average, a Flemish municipality levies 21 own local taxes, but there is a large difference among the municipalities. At the one end, the municipality with the largest number of taxes levies 42 taxes, while, at the other end, one municipality only imposes 3 own taxes (Agentschap voor Binnenlands Bestuur (Agency for local government), 2008). These figures give an impression of the diversity of the local tax system and the real proliferation of own local taxes.

Local governments use this tax revenue to provide public goods and services. In fact, local governments are the principal public sector investors. On average they contribute for approximately $50 \%$ to the gross creation of new public capital (Belfius, 2012a). The most important spending categories are traffic, public cleansing and urban development, and public administration, each responsible for at least $15 \%$ of total investments. Investments in 
culture, economics, education and to a lesser extent safety, are other important investment categories of Flemish municipalities (Belfius, 2012b).

\section{Methodology}

In order to examine how local taxes, local public spending and tax compliance costs impact firm profitability in the hospitality industry, we estimate a regression model which includes the fiscal policy variables, while controlling for firm-specific as well as region-specific variables. More specifically, the following basic equation will be estimated:

$$
\begin{aligned}
\text { ROA }_{i, t}= & \beta_{0 i}+\beta_{1} A G E_{i, t-1}+\beta_{2} \text { SIZE }_{i, t-1}+\beta_{3} L_{E V} V_{i, t-1}+\beta_{4} \text { DENSITY }_{i, t}+\beta_{5} \text { TAX }_{-} \text {PROVINCE }_{i, t} \\
& +\beta_{6} \text { TAX }_{i, t}+\beta_{7} \operatorname{SPENDING}_{i, t}+\beta_{8} \text { CC }_{i, t}+\beta_{9} Y_{t}+\varepsilon_{i, t}
\end{aligned}
$$

Where $R O A_{i, t}$ refers to return on assets for firm $i$ in year $t, \beta_{0 i}$ is the firm-specific effect, $A G E$ is the age of the company, SIZE denotes the size of the company, LEV refers to leverage, DENSITY is population density at the municipal level, TAX_PROVINCE refers to the provincial surcharge on the property tax paid by the businesses, TAX is the average tax paid by firms in the municipality, SPENDING denotes public spending, $C C$ is the compliance cost, $Y$ refers to a vector of year dummies and $\varepsilon$ represents the error term. Year dummies were included to account for annual shocks. As ROA is determined by the beginning values of the firm-specific variables, rather than their ending value, a one-year-lag is used for these variables. A second reason for using the lagged values of the independent variables is related to the potential problem of endogeneity: the lagged values of the independent variables are less likely to be correlated with the current disturbance term. A second regression model will be estimated where spending is disentangled into the different subcategories, being safety, infrastructure, 
education, and other productive spending, including inter alia trade fairs and tourism support.

In regression equation (1), both TAX and SPENDING are simultaneously included. Otherwise, any negative effect of TAX will be underestimated, since the coefficient also reflects any positive effect of increased public spending that is associated with the tax increase (Goss \& Phillips, 1994). Another important estimation issue is the presence of unobserved heterogeneity. If unobserved heterogeneity is present, then failing to control for it may result in biased estimates (Gujarati \& Porter, 2009). An F-test indicated that there are indeed firm-specific effects. Therefore, pooled OLS is not an appropriate estimation method. Instead, fixed effects or random effects should be applied, depending on whether the unobserved heterogeneity is correlated with the explanatory variables. Fixed effects is the appropriate estimation procedure, if the firm-specific effect is correlated with the explanatory variables. Otherwise, random effects can be used, which is a more efficient estimation technique than fixed effects. The Hausman test rejected the null hypothesis of no correlation between the firm-specific effect and the explanatory variables. Therefore, fixed effects will be applied. This estimation method mitigates a potential omitted variable problem, since fixed effects estimation is equal to demeaning all variables, thereby eliminating the firm-specific effect that subsumes all time-invariant characteristics. The standard errors are robust to heteroscedasticity and serial correlation.

\section{Data and sample}

Financial data on the firms are obtained from the Belfirst database from Bureau Van Dijk. This dataset provides the information contained in the financial statements of Belgian companies. Firms within the hospitality industry were extracted from this database. These 
firms are categorized under NACE codes (Nomenclature statistique des activités économiques dans la Communauté européenne) 55 and 56. NACE 55 encompasses all accommodation firms, while restaurants and bars are classified under NACE 56. The fiscal variables are gathered from a dataset obtained from the Flemish government. This dataset provided us with all spending and tax categories and the corresponding amounts paid or received by the municipalities. Data about the municipalities' population, area and persons employed are retrieved from Local Statistics Flanders, a website of the Flemish government. Our data cover the period 2004-2007 and are thus limited to the period before the pact between the Flemish government and the municipalities was issued. This pact reduced the fiscal autonomy of the Flemish municipalities (Smolders \& Goeminne, 2010).

Since fixed effects demeans all variables, every firm should appear at least two years in the sample, before being incorporated. Furthermore, since ratios typically generate large outliers, we removed the $5 \%$ highest and lowest values for the two firm-specific ratio variables: return on assets and leverage. Next, we eliminated all firms with negative equity. Finally, we required that firms had on average at least five employees. The exclusion of micro-firms is typical in empirical work and is often motivated by the fact these companies have specific characteristics; i.e. relatively young, fast growing, often occurring funding shortage (Reid, 1996) and are often founded for fiscal motives (Heyman et al 2008). The final dataset comprised 3,069 firm-year observations, spread over 912 firms. Respectively 1,710, 1,267 and 92 firm-year observations originate from companies with less than 10, between 10 and 50 and more than 50 employees.

\section{Dependent variable}


Our measure of profitability is return on assets. It is preferred above return on equity, since the latter is not independent of the firm's capital structure. Return on assets is calculated as income before taxes plus financial costs, divided by total assets and multiplied by one hundred. This measure is calculated before corporate income tax, however all tax payments made in order to comply with the local tax system are subsumed under the operational costs of the firm and are thus still included in the return on assets.

\section{Fiscal policy variables}

We construct three different fiscal policy variables: a tax variable, a public spending variable and a variable reflecting compliance costs. The tax variable is calculated as the percentage of municipal tax revenue that was paid by either businesses alone, or by businesses and citizens, multiplied by the total tax revenue of each municipality. Further, to account for scale effects, the variable was divided by total persons employed in the municipality. This variable is unique at the municipality level. If the local tax cost is a significant proportion of companies' operational costs, we expect a negative significant coefficient on this variable.

The public spending variable is measured as productive spending divided by total persons employed in the municipality. Based on the literature, productive spending is defined as the amount in euros spent on safety, infrastructure, education and other productive spending, which includes inter alia organizing trade fairs and tourism support. In the second regression model we disentangle the public spending variable into the four different subcategories mentioned above. Each variable is again divided by total persons employed in the municipality to account for different scale effects.

Compliance costs are measured as the number of different taxes within each municipality. This is an indication of the complexity of the tax regulations, which is viewed as an important 
determinant of compliance costs (Vaillancourt, 1987). Contrary to other studies, we do not try to estimate the exact compliance costs. Prior studies attempting to calculate the exact compliance costs generally used survey evidence. However, respondents are likely to either overstate or understate the true compliance cost (Eichfelder \& Schorn, 2012). A further difficulty is the fact that there is an overlap between accounting and compliance costs which makes it difficult to allocate the incurred costs correctly (Tran-Nam et al., 2000). Therefore, doubts have risen about the reliability of these estimates (Pope, 1993). We overcome these issues by using an objective measure of compliance costs, namely the number of taxes.

\section{Control variables}

We include several firm-specific control variables : age, size and leverage. Age is measured as the natural logarithm of the years since incorporation. Size is measured as the natural logarithm of total employees in fulltime equivalents. The last firm-specific control variable is leverage, which is measured as financial debt, divided by equity.

Next to the firm-specific variables, we also incorporate a municipal-specific variable, density, and a provincial variable, provincial taxes. Density is included to reflect the demand side of firms in the hospitality industry. Densely populated cities have more potential customers nearby and can attract more visitors and tourists, which can result in heightened demand and thus a higher level of firm profitability. On the other hand, population density can represent increased land rents, which can heighten the firm's operational costs. Density is measured as inhabitants per square kilometer.

Since our dataset is limited to the Flemish region, tax differentials between the different Belgian regions will not influence our results. However, the provinces, which are the intermediary government level between the regions and the municipalities, also possess tax 
legislative power. To account for the different provincial tax rates, which can affect firm profitability, we include the variable provincial taxes. This variable represents the burden imposed on businesses by the provinces and is measured as the amount of taxes paid by the businesses for the provincial surcharge on the property tax ${ }^{1}$, and divided by total persons employed within the province.

\section{Results}

\section{Descriptive statistics}

The descriptive statistics of each variable are presented in table 1.

[Insert table 1]

Mean return on assets is equal to $6.3 \%$ over the period of analysis. The firms are on average over ten years old and have almost 10 employees, measured in full time equivalents. The hospitality firms are rather highly geared; with on average the financial debt exceeding the amount of equity. The variable DENSITY displays a rather high variation, ranging from approximately 50 inhabitants per $\mathrm{km}^{2}$ to 3,141 inhabitants. In our sample, firms pay an average amount of 693 euro per employee for local taxes divided over 15 types of taxes. The government, in turn, spends 1,687 euro per employee on productive public goods and services. On average, of the different spending categories, most money is spent on safety, while education exhibits the largest variety between municipalities. On average, the provincial taxes paid by firms amount to 75 euro per employee. This is considerably smaller than the average amount paid to comply with municipal taxation.

Table 2 contains the Pearson correlations. We see that the correlation between TAX and the spending variables is high. This is not surprising since governments depend for almost $50 \%$ of 
their revenues on local taxes. So, a decline or increase in these taxes is likely to influence government spending to a high extent. Despite the high correlations, both the tax and the spending variables should be included simultaneously in the regression equation. Otherwise, the effect of taxes might be underestimated, since the coefficient also reflects the positive effect of public spending associated with the tax (Goss \& Phillips, 1994). Of the different spending categories, education seems to be the least correlated with the other spending variables. Furthermore, provincial taxes and municipal taxes are negatively correlated, indicating that municipalities in provinces with low provincial taxes are more likely to levy higher taxes themselves. This might be an indication of substitutability between the different levels of government taxation.

[Insert table 2]

Finally, table 3 shows the descriptive statistics per year for the fiscal variables. It appears that all our variables of interest (TAX, SPENDING, CC) vary heavily among municipalities. Furthermore, we can see that for both TAX and CC the peak is reached in 2004 and 2005. The spending categories safety and infrastructure decline over time while education expenditures seem to be increasing.

[Insert table 3]

\section{Regression results}

The regression results of equation (1) are presented in column a of table 4. Year dummies are included but not reported for reasons of parsimony.

[Insert table 4] 
As concerns the firm-specific control variables, age and size display a negative significant relation with firm profitability, while leverage has a positive impact. The negative effect of age suggests that older firms lack sufficient dynamism to respond to changing market preferences and consequently experience lower levels of financial performance. This negative effect was also found by Cowling (2004) and Roper (1999). The negative significant coefficient of size is surprising. Theoretically, both a positive and a negative effect could be expected, but we suggested that a positive effect would be more probable because our sample consists of mainly small firms. However, in a recent study, investigating the profitability of Taiwanese hotels, Chen (2010) also detected a negative effect of size on firms' return on assets. Furthermore, Jang and Park (2011) also found a negative, albeit an insignificant impact, of size on firm profitability for restaurants, using fixed effects estimation. Contrary to age and size, leverage exerts a positive influence on firm performance, indicating that debt disciplines managers and owners to efficiently run their company.

With respect to the municipal and provincial control variables, we found that population density positively affects the profitability of hospitality firms, while provincial taxes do not have a significant influence. The positive effect of density suggests that densely populated municipalities indeed experience a higher demand. This might occur because there are more potential customers nearby and because larger cities better succeed in attracting tourists from abroad or from other municipalities. Contrary to density, the provincial taxes do not appear to impact firm profitability. Although taxes increase the operational costs, the insignificant coefficient suggests that the amount of provincial taxes is not substantial enough to affect firm-level profitability. 
Regarding the variables of interest, we see that the amount of taxes paid per employee has a negative significant impact on a firm's profitability, while spending has a positive significant influence. The coefficient on the variable TAX implies that when TAX increases by one standard deviation, firm profitability decreases by 0.71 standard deviations. If TAX raises from the $25^{\text {th }}$ to the $75^{\text {th }}$ percentile ${ }^{2}$, there is a decline in firm profitability of 4.1 percentage points. These calculations show that the effect of local taxes is certainly economically significant. As for SPENDING, a one standard deviation increase corresponds to an increase of 0.31 standard deviations of firm profitability. If expressed otherwise, we can state that if SPENDING increases from the $25^{\text {th }}$ to the $75^{\text {th }}$ percentile ${ }^{3}$, firm profitability goes up by 2.79 percentage points. Whereas the tax variable is significant at the $1 \%$ level, the spending variable is only marginally significant at the $10 \%$ level. As concerns the compliance costs, although this variable is negatively associated with firm performance, the coefficient is statistically insignificant.

Next, a second regression model is estimated, where spending is disentangled into the four separate subcategories: spending on safety, infrastructure, education, which are perceived as the most important spending items for firms (Brülhart et al., 2012), and other productive spending. Column (b) in table 4 shows the results of this second regression. The findings are fairly stable compared with the first regression. With respect to the control variables, all signs and significance levels remain unchanged. Regarding the variable $T A X$, we see that the coefficient is only slightly reduced and is still significant. As before, compliance costs do not affect firm performance significantly. As concerns the four spending categories, we find that only other productive spending exerts a positive significant effect on firm profitability. The coefficient corresponds to an increase of 1.84 percentage points if other productive spending raises from the $25^{\text {th }}$ to the $75^{\text {th }}$ percentile ${ }^{4}$. In terms of standard deviations, the 
coefficient implies that when other productive spending augments by one standard deviation, firm profitability increases by 0.29 standard deviations.

\section{Robustness checks}

An alternative measure for size is the natural logarithm of total assets. As a robustness check, we performed the regression with the natural logarithm of total assets as a proxy for firm size (column (b) of table 5). The sign and significance of all control variables and of all variables of interest (tax, spending and compliance costs) are the same as when the number of workers is used as a proxy for firm size.

[Insert table 5]

Column (b) of table 5 includes the results of a regression which includes an interaction effect between TAX and SIZE. As mentioned before, the lump-sum character of municipal taxation raises the expectation that taxation should burden large companies relatively less. When SIZE in the interaction effect is measured as a dummy ('one' for companies with more than 50 employees) the coefficient of the interaction effect is highly significant $(p<0.01)$ and positive (0.006). This means that the effect of taxation is less negative for large companies. When SIZE in the interaction effect was measured continuously, there was no significant coefficient on the interaction effect. This indicates that marginal differences in the size of companies do not provoke changes in the effect of taxes on profitability, but rather the effect is only outspoken between the two categories of 'small' and 'large' companies.

\section{Discussion}

This paper aims to explore whether and how local fiscal policy affects the profitability of firms within the Flemish hospitality industry. The findings reveal that local fiscal policy does 
indeed affect firm profitability. Taxes are found to negatively impact firm financial performance and spending positively. Due to the lump-sum nature of local taxation in Flanders, the profitability of the large companies in our sample is affected less negatively. The magnitude of the tax effect is important from an economic point of view. This suggests that municipal taxes should not be considered as an insignificant proportion of total business costs. Furthermore, the negative significant tax effect found in our study largely exceeds the public spending impact, both in terms of economic and statistical significance. This indicates that taxes have a larger effect on firm financial performance than public spending. This is exactly what one would expect, because taxes directly influence a firm's profitability, while public spending only has an indirect impact.

When examined more in detail, we find that of the four spending subcategories only other productive spending has a positive significant impact. Safety, infrastructure and education apparently do not have an observable impact on financial performance. This is contrary to what has been documented in academic research so far. Although the effects differ considerably across papers, in general, infrastructure, safety, and to a lesser extent education, have been found to positively affect businesses (Fisher, 1997). However, there are two important reasons why our results may differ from the mainstream findings. First, prior research mostly examined the effect of public spending at larger geographic regions, for example states in the United States. It has been acknowledged that the effect of spending would decrease with geographical scale, due to spillover effects (Berechman et al., 2006; Munnell, 1992). Secondly, previous research mainly focused on the manufacturing industry. However, it has been argued that the effects of public spending can differ considerably between industries (Fisher, 1997). As concerns the manufacturing industry, education is said to increase the productivity of workers, while good infrastructure eases the 
transportation of the products, which can lower the operational costs of the firm. However, these reasons do not apply to the hospitality industry. Hospitality firms employ foremost low-skilled employees and may thus react less responsively to education spending. Furthermore, service firms are less dependent on the state of the roads. Due to these differences, our findings are not completely surprising. Aggregate spending and other productive spending, such as organizing trade fairs and tourism support, can attract more citizens and tourists to the municipality, which positively affects the demand side of hospitality firms.

Being the first study to explore how local fiscal policy affects firm profitability, we experienced some limitations in terms of the precision of the fiscal variables. All the fiscal policy variables are measured at the level of the municipality and are not unique to the firm level. Therefore, we are unaware of the true tax cost and the exact number of the different tax types for each firm. An important local tax is, for example, the tax on terraces. However, we do not know which restaurants and hotels actually have a terrace and correspondingly should pay for it. Furthermore, although our measure of compliance cost is objective, it does not capture the different requirements imposed by the taxes, which can have an influence on the associated compliance cost. These inaccuracies in the data are not specific to our study, but are rather inherent in this kind of research (Wasylenko, 1997). Further improving the precision of fiscal data could be a suggestion for future research, although it will demand a lot of effort to have precise data on the tax paid by each firm separately, as well as the number of taxes. Although our measures might be imprecise, we made some considerable contributions and improvements compared to prior research. First, we examined the effect of taxes levied by municipal governments, which are the lowest entities with fiscal autonomy. Second, this paper is one of the first to examine the effect of taxes at the firm 
level. Third, we are the first to assess the impact of compliance costs associated with local taxes and used an objective measure of tax compliance costs. Fourth, we have chosen the hospitality industry as our research setting. This is an important contribution since prior research has mostly focused on the manufacturing industry and since it is argued that the effects of taxes and spending may differ considerably across industries (Fisher, 1997). Finally, we fulfilled all criteria for improving the reliability of our estimates: we included fixed effects, incorporated the tax and the spending variables simultaneously in the regression equation and measured the total tax cost and not only the tax rate.

As a second shortcoming, we used expenditures to proxy for public goods and services delivered by local governments. Although this is a frequently used measure, it has been suggested that expenditures do not capture the quality of the goods and services provided. Dalenberg and Partridge (1995), for example, after finding a negative coefficient on highway spending with respect to metropolitan area employment, argued that increased expenditures may reflect deteriorating roads. Furthermore, Charney (1983) and Fisher (1997) postulated that the cost of providing a certain good or service depends inter alia on the geographical or population characteristics of the region and can thus differ significantly between municipalities, without reflecting quality or quantity differences. Future research should use more qualitative evidence of how firms perceive the goods and services offered by the municipalities.

\section{Conclusions}

To the best of our knowledge this paper is the first to examine the effect of local fiscal policy on the profitability of Flemish hospitality firms. The Flemish hospitality industry provides a unique and interesting context for examining the effects of local fiscal policy, since Flemish 
municipalities have far-ranging fiscal autonomy. This has led to a real proliferation of local taxes, of which a lot are specific to the hospitality industry.

This paper analyzes three aspects of local fiscal policy: taxes, spending and tax compliance costs. Previous research mostly focused on the impact of taxes and spending on the state or county level, while studies using municipality data are rather limited. Furthermore, most of the studies used aggregate economic outcome measures, while this study focused on firmlevel profitability. Moreover, as far as we know, no prior study has ever investigated whether local taxes generate substantial compliance costs.

The findings of this study reveal that local taxes hamper firm financial performance, while aggregate public spending increases firm performance. Both effects are economic significant, showing that municipal taxes may not be considered as an insignificant part of the total business costs. Furthermore, when public spending is disentangled into different subcategories, such as safety, infrastructure, education, and other productive spending, only other productive spending appears to significantly affect firm profitability. Finally, we do not find any evidence of substantial compliance costs associated with local taxes. These findings suggest that the proliferation of local taxes in se has not inhibited the hospitality firms, but that the local governments should be careful in raising the total tax cost.

\section{Notes}

\footnotetext{
${ }^{1}$ Although provinces levy three types of taxes, the surcharge on the property tax is the most important and accounts for $75,7 \%$ of total provincial tax revenue. The other provincial tax
} 
types include the general provincial tax and various other small taxes, which are mainly levied in only one province (Belfius, 2012b).

${ }^{2}$ For the tax variable, the values for the $25^{\text {th }}$ and the $75^{\text {th }}$ percentile are 449.91 and 735.24 , respectively.

${ }^{3}$ For the public spending variable, the values for the $25^{\text {th }}$ and the $75^{\text {th }}$ percentile are 1037.32 and 2010.82, respectively.

${ }^{4}$ For the other productive spending variable, the values of the $25^{\text {th }}$ and the $75^{\text {th }}$ percentile amount to 197.57 and 410.77 , respectively.

\section{References}

Agentschap voor Binnenlands Bestuur [Agency for local government]. (2008). Jaarbeeld 2008. Lokaal besturen en samenleven in diversiteit in Vlaanderen [Factsheet 2008. Locally governing and coexistence in diversity in Flanders]. Retrieved from http://binnenland.vlaanderen.be/

Ariff, M., Ismail, Z., \& Loh, A.L.C. (1997). Compliance costs of corporate income taxation in Singapore. Journal of Business Finance \& Accounting, 24(9/10), 1253-1268.

Aschauer, D.A. (1989). Is public expenditure productive? Journal of Monetary Economics, $23(2), 177-200$.

Bartik, T.J. (1992). The effects of state and local taxes on economic development: a review of recent research. Economic Development Quarterly, 6(1), 102-111. 
Becker, S.O., Egger, P.H., \& Merlo, V. (2012). How low business tax rates attract MNE activity: municipality-level evidence from Germany. Journal of Public Economics, 96(9/10), 698-711.

Belfius. (2012a). De investeringen van de gemeenten [The investments of the municipalities]. Retrieved from https://www.belfius.be

Belfius. (2012b). Lokale financiën. Gemeenten en provincies [Local budgets. Municipalities and provinces]. Retrieved from https://www.belfius.be

Berechman, J., Ozmen, D., \& Ozbay, K. (2006). Empirical analysis of transportation investment and economic development at state, county and municipality levels. Transportation, 33(6), 537-551.

Bruce, D., \& Deskins, J. (2012). Can state tax policies be used to promote entrepreneurial activity? Small Business Economics, 38(4), 375-397.

Brülhart, M., Jametti, M., \& Schmidheiny, K. (2012). Do agglomeration economies reduce the sensitivity of firm location to tax differentials? The Economic Journal, 122(563), 1069-1093.

Capon, N., Farley, J.U., \& Hoenig, S. (1990). Determinants of financial performance: a metaanalysis. Management Science, 36(10), 1143-1159.

Charney, A.H. (1983). Intraurban manufacturing location decisions and local tax differentials. Journal of Urban Economics, 14(2), 184-205.

Chen, M. (2010). The economy, tourism growth and corporate performance in the Taiwanese hotel industry. Tourism Management, 31(5), 665-675. 
Chittenden, F., Kauser, S., \& Poutziouris, P. (2003). Tax regulation and small business in the USA, UK, Australia and New Zealand. International Small Business Journal, 21(1), 93-115.

Chittenden, F., Poutziouris, P., Michaelas, N., \& Watts, T. (1999). Taxation and small firms: creating incentives for the reinvestment of profits. Environment and Planning C: Government and Policy, 17(3), 271-286.

Chung, W., \& Kalnins, A. (2001). Agglomeration effects and performance: a test of the Texas lodging industry. Strategic Management Journal, 22(10), 969-988.

Cohen, J.P., \& Morrison Paul, C.J. (2004). Public infrastructure investment, interstate spatial spillovers, and manufacturing costs. The Review of Economics and Statistics, 86(2), 551-560.

Cowling, M. (2004). The growth-profit nexus. Small Business Economics, 22(1), 1-9.

Dalenberg, D.R., \& Partridge, M.D. (1995). The effects of taxes, expenditures, and public infrastructure on metropolitan area employment. Journal of Regional Sciences, 35(4), 617640.

Douma, S., George, R., \& Kabir, R. (2006). Foreign and domestic ownership, business groups, and firm performance: evidence from a large emerging market. Strategic Management Journal, 27(7), 637-657.

Duranton, G., Gobillon, L., \& Overman, H.G. (2011). Assessing the effects of local taxation using microgeographic data. The Economic Journal, 121(555), 1017-1046.

Eichfelder, S., \& Schorn, M. (2012). Tax compliance costs: a business-administration perspective. FinanzArchiv, 68(2), 191-230. 
Feld, L.P., \& Kirchgässner, G. (2002). The impact of corporate and personal income taxes on the location of firms and on employment: some panel evidence for the Swiss cantons. Journal of Public Economics, 87(1), 129-155.

Fisher, R.C. (1997). The effects of state and local public services on economic development. New England Economic Review, (March/April), 53-67.

Gabe, T.M., \& Bell, K.P. (2004). Tradeoffs between local taxes and government spending as determinants of business location. Journal of Regional Science, 44(1), 21-41.

Gedajlovic, E., \& Shapiro, D.M. (2002). Ownership structure and firm profitability in Japan. The Academy of Management Journal, 45(3), 565-575.

Glancey, K. (1998). Determinants of growth and profitability in small entrepreneurial firms. International Journal of Entrepreneurial Behaviour \& Research, 4(1), 18-27.

Goddard, J., Tavakoli, M. \& Wilson, J. (2009) Sources of variation in firm profitability and growth. Journal of Business Research, 62(4), 495-508.

Goss, E.P., \& Phillips, J.M. (1994). State employment growth: the impact of taxes and economic development agency spending. Growth and Change, 25(3), 287-300.

Gujarati, D.N., \& Porter, D.C. (2009). Basic Econometrics (5th Ed.). New York, NY: McGrawHill.

Gupta, S., \& Mills, L.F. (2003). Does disconformity in state corporate income tax systems affect compliance cost burdens? National Tax Journal, 56(2), 355-371.

Hanefah, M., Ariff, 
M., \& Kasipillai, J. (2002). Compliance costs of small and medium enterprises. Journal of Australian Taxation, 4(1), 73-97.

Helms, L.J. (1985). The effect of state and local taxes on economic growth: a time series cross section approach. The Review of Economics and Statistics, 67(4), 574-582.

Heyman, D., Deloof, M., \& Ooghe, H. (2008). The Financial Structure of Private Held Belgian Firms. Small Business Economics, 30 (3), 301-313.

Holcombe, R.G., \& Lacombe, D.J. (2004). The effect of state income taxation on per capita income growth. Public Finance Review, 32(3), 292-312.

Huang, J., \& Chaloupka, F.J. (2013). The economic impact of state cigarette taxes and smokefree air policies on convenience stores. Tobacco Control, 22(2), 91-96.

Jang, S., \& Park, K. (2011). Inter-relationship between firm growth and profitability. International Journal of Hospitality Management, 30(4), 1027-1035.

Jensen, M.C. (1986). Agency costs of free cash flow, corporate finance and takeovers. The American Economic Review, 76(2), 323-329.

Jensen, M.C., \& Meckling, W.H. (1976). Theory of the firm: managerial behavior, agency costs and ownership structure. Journal of Financial Economics, 3(4), 305-360.

Jofre-Monseny , J., \& Solé-Ollé, A. (2010). Tax differentials in intraregional firm location: evidence from new manufacturing establishments in Spanish municipalities. Regional Studies, 44(6), 663-677.

Klun, M., \& Blazic, H. (2005). Tax compliance costs for companies in Slovenia and Croatia. FinanzArchiv, 61(3), 418-437. 
Laureys, C., \& Van Assche, A. (2012). Ondernemersbelastingen in de 13 Vlaamse centrumsteden en de stad Brussel. Studiedienst Unizo. [Business taxes in the 13 Flemish central cities and the city of Brussels. Research Department Unizo]. Retrieved from http://www.unizo.be/

Leroy, J. (2005). Recente evolutie van de gemeentelijke fiscaliteit in Vlaanderen [Recent evolution of municipal fiscal policy in Flanders]. Documentatieblad Federale Overheidsdienst Financiën-België [Journal of the Federal Public Service Finance-Belgium], 65(2), 107-158.

Madanoglu, M., Lee, K., \& Castrogiovanni, G.J. (2011). Franchising and firm financial performance among U.S. restaurants. Journal of Retailing, 87(3), 406-417.

Mark, S.T., McGuire, T.J., \& Papke, L.E. (2000). The influence of taxes on employment and population growth: evidence from the Washington, D.C. metropolitan area. National Tax Journal, 53(1), 105-123.

Munnell, A.H. , \& Cook, L.M. (1990). How does public infrastructure affect regional economic performance? New England Economic Review, (September/October), 11-32.

Munnell, A.H. (1992). Policy watch: infrastructure investment and economic growth. The Journal of Economic Perspectives, 6(4), 189-198.

Nunes, P.J.M., Serrasqueiro, Z.M., \& Sequeira, T. N. (2009). Profitability in Portuguese service industries: a panel data approach. The Service Industries Journal, 29(5), 693-707.

Phillips, J.M., \& Goss, E.P. (1995). The effect of state and local taxes on economic development: a meta-analysis. Southern Economic Journal, 62(2), 320-333. 
Pope, J. (1993). The compliance costs of taxation in Australia and tax simplification: the issues. Australian Journal of Management, 18(1), 69-89.

Pope, J., Fayle, R., \& Chen, D. (1991). The compliance costs of public companies' income taxation in Australia 1986/87. Sydney: Australian Tax Research Foundation.

PricewaterhouseCoopers. (2013). Paying Taxes 2013. The global picture. Retrieved from http://www.pwc.nl/

Rathelot, R., \& Sillard, P. (2008). The importance of local corporate taxes in business location decisions: evidence from French micro data. The Economic Journal, 118(527), 499-514.

Reid, G.C. (1996). Mature micro-firms and their experience of funding shortages. Small Business Economics, 8(1), 27-37.

Roper, S. (1999). Modelling small business growth and profitability. Small Business Economics, 13(3), 235-252.

Sandford, C., Godwin, M., \& Hardwick, P. (1989). Administrative and compliance costs of taxation. Bath: Fiscal publications.

Schoonjans, B., Van Cauwenberge, P., Reekmans, C., \& Simoens, G. (2011). A survey of tax compliance costs of Flemish SMEs: magnitude and determinants. Environment and Planning C: Government and Policy, 29(4), 605-621.

Serrasqueiro, Z.S., \& Nunes, P.M. (2008). Performance and size: empirical evidence from Portuguese SMEs. Small Business Economics, 31(2), 195-217.

Slemrod, J., \& Blumenthal, M. (1996). The income tax compliance cost of big business. Public Finance Quarterly, 24(4), 411-438. 
Smolders, C., \& Goeminne, S. (2010). Fiscale beperkingen en fiscaliteit: de verwachte impact van het fiscaal pact op de financiën en schuldenlast van Vlaamse gemeenten [Fiscal limitations and fiscal policy: de expected impact of the fiscal pact on the budgets and the indebtedness of the Flemish municipalities]. Documentatieblad Federale Overheidsdienst Financiën-België [Journal of the Federal Public Service Finance-Belgium], 70(3), 91-124.

Smolders, C., Goeminne, S., \& Bloemen, L. (2005). Lokale bedrijfsbelastingen: vormen, zin en wenselijkheid. Samenvattende inzichten \& beleidsaanbevelingen [Local business tax: outline, meaning and desirability. Summarized findings \& policy recommendations]. Steunpunt beleidsrelevant onderzoek Bestuurlijke Organisatie Vlaanderen [Centre for Policy Research Governmental Organization Flanders]. Retrieved from http://www.steunpuntbov.be/

Smulders, S., \& Stiglingh, M. (2008). Annual tax compliance costs for small businesses: a survey of tax practitioners in South Africa. South African Journal of Economic and Management Sciences, 11(3), 354-371.

Tannenwald, R. (1996). State business tax climate: how should it be measured and how important is it? New England Economic Review, (January/February), 23-38.

Tran-Nam, B., Evans, C., Walpole, M., \& Ritchie, K. (2000). Tax compliance costs: research methodology and empirical evidence from Australia. National Tax Journal, 53(2), 229-252.

Vaillancourt, F. (1987). The compliance costs of taxes on businesses and individuals: a review of the evidence. Public Finance, 42(3), 395-414.

Wasylenko, M.J. (1997). Taxation and economic development: the state of the economic literature. New England Economic Review, (March/April), 37-52. 